\title{
Bio-Electroreduction of Chromium (VI) using Immobilized Sulfate Reducing Bacteria on Conductive Microbial Cellulose Biocathode
}

\section{Mahshid Loloei}

Tarbiat Modares University

Abbas Rezaee ( $\square$ abbasrezaee@yahoo.com )

Tarbiat Modares university https://orcid.org/0000-0001-5042-2963

Ghazaleh Ghods

Tarbiat Modares University

\section{Research Article}

Keywords: Microbial cellulose, Conductive polymer, Bio-electroreduction, $\mathrm{Cr}(\mathrm{VI})$, SRB

Posted Date: July 15th, 2021

DOl: https://doi.org/10.21203/rs.3.rs-688439/v1

License: (c) (i) This work is licensed under a Creative Commons Attribution 4.0 International License.

Read Full License 


\section{Abstract}

The present study evaluated effect of conductive microbial cellulose (MC) biocathode as a carbohyrate biopolymer in hexavalent chromium bio-electroreduction using immobilized sulfate reducing bacteria (SRB). The morphology studies using SEM shows that the biofilm of SRB was formed a good density on the conductive microbial cellulose biocathode. The Brunauer, Emmett and Teller (BET) analysis revealed that the particle-size distribution in the conductive biocathode was $0.9 \mathrm{~nm}$. The kinetic studies shows that the $\mathrm{Cr}(\mathrm{VI})$ removal process fallow of pseudo-first-order kinetics with a constant rate was $0.6 \mathrm{~h}^{-1}$. The energy consumption of the bio-electroreduction system was $2.7 \times 10^{-2} \mathrm{kWh} / \mathrm{m}^{3}$. The EDXA spectrum of sediments showed the presence of chromium peak, indicating that $\mathrm{Cr}(\mathrm{VI})$ was reduced on the bioresuction system. The obtained results indicate that proposed bio-electroreduction system using immobilized sulfate reducing bacteria on the conductive microbial cellulose biocathode could be an efficient method for chromium bio-reduction from wastewaters.

\section{Introduction}

The microbial cellulose (MC) as a carbohyrate biopolymer composite presentes various prporties such as, high tensile strength, low weight, superabsorption, water holding capacity and high ratio of the surface to the volume [1,2]. The MC is not conductive and it could not utilized in the bioelectrochemical process as the electrodes. Various methods have been presented for incerasing of the electrical conductivity of polymers and the MC [3]. Polyaniline is a polymer with high environmental stability, high electrical conductivity, easy process, and very cost-effective. But its application is limited due to its relatively low mechanical strength [4]. On the other hand, industrialization and human activities produce large quantities of industrial wastewater containing heavy metals such as $\mathrm{Cr}(\mathrm{VI})$. The $\mathrm{Cr}(\mathrm{VI})$ is highly mobile in the environment and has carcinogenic and harmful properties for living tissues. Cleaning up the contaminated areas with chromium is one of the priorities of the authorities in the all worlds $[5,6]$. Various technologies have been proposed for chromium removal from wastewater sources. Energy consumption, using chemicals and hazard waste are the major problems in different physical and chemical utilized technologies [7]. Despite abundant advantages, the biological treatment methods including aerobic and anaerobic approaches have shortcomings in the removal of different contaminants. These processes are very slow, especially in high concentrations of heavy metals, and require a very long time. Adaptation and start-up period of these systems are usually long and thus expensive [8]. The degree of bioreduction is strongly dependent on the type of the wastewater and their environmental conditions. The chromium bioreduction efficiency is often incomplete in the environmental conditions and some amounts of chromium always remain in the wastewater [8, 9]. Microbial electrochemical system (MES) is an attractive technology in wastewater treatment that uses pure or mixed microorganisms as attached biofilm on the electrodes [10]. In the systems, oxidation and reduction reactions are catalyzed by biofilms-electrodes interaction. MES is a flexible technology used in wastewater treatment, trace element removal, energy producing. The microbial biofilm electric stimulation can improve the pollutant removal because of microbial metabolism enhancing [11]. In this way, the bio- 
electrochemical processes have received a lot of attention from researchers in reduction and removal of heavy metals and energy of the system $[12,13]$. In the MES, the micro-organisms are used to catalyze the oxidation-reduction reaction on the surface of an electrodes. Using bio-cathodes in heavy metals removal is a fascinating subject for research. The growth of microorganisms on the cathode for accepting electrons as a biocatalyst have received much attention [14]. This reduces the need to use reduction catalysts and shortens the start-up period of bio electrochemical systems. Also, Bioelectrical reactors (BER) are an effective way to stimulate microbial metabolism [10]. The positive impact of electric current to remove contaminants such as nitrates have been studied at 0-100 mA currents [15]. The sulfatereducing bacteria (SRB) are anaerobic bacteria with a low growth rate $\left(1.9 * 10^{-9} \mathrm{~d}^{-1}\right)$ which have many applications in bioelectrochemistry and environmental biotechnology [16]. Some of the important applications of these bacteria are in the biological reduction process of heavy metals. This process consists of two stages. In the first stage, SRB oxidize simple organic compounds under anaerobic conditions and produce sulfide and bicarbonate ions (Eq. 1). In the second stage, the hydrogen sulfide reacts with dissolved metals to form insoluble deposits of sulfide (Eq. 2).

$$
2 \mathrm{CH}_{2} \mathrm{O}+\mathrm{SO}_{4}^{2-} \rightarrow \mathrm{H}_{2} \mathrm{~S}+2 \mathrm{HCO}_{3}^{-}
$$

1

$$
M e^{2+}+H_{2} S \rightarrow M e S_{\downarrow}+2 H^{+}(M e=\text { Metal })
$$

2

SRB can indirectly reduce $\mathrm{Cr}(\mathrm{VI})$ ions through the production of $\mathrm{H}_{2} \mathrm{~S}$ (Eq. 3).

$$
3 H S^{-}+2 C r^{6+} \rightarrow 3 S^{\circ}+2 C r_{\downarrow}^{3+}+3 H^{+}(3)
$$

This method not only can remove heavy metals from wastewater, but also can recover precious metals from sulfide deposits. Reported studies indicate the positive impact of an electric current on the quicker removal of sulfate from crude oil by SRB [17]. The present study investigated the effect of the electric current on the removal of $\mathrm{Cr}(\mathrm{VI})$ in high concentrations using SRB in a bioelectrochemical process by immobilization of bacteria on polyaniconductive MC carbohyrate biopolymer. To the best of our knowledge and based on the literature, there is no previous report on the bioelectro-stimulation immobilized sulfate reducing bacteria on $\mathrm{MC}$ /polyaniline biocathode for chromium removal. Hence, the objective of present study was to investigate a bio-reduction system for chromium removal using the bioelectrochemical system. It is expected that experimental results could be used as a reference for the heavy metal removal in bioelectrochemical systems for wastewater treatment..

\section{Materials And Methods}


All materials used in this study were of the pure grade. The stock solution of $\mathrm{Cr}(\mathrm{VI})$ was prepared from a solution of potassium dichromate in distilled water. The preparation and properties of the polyanilinecellulose biopolymer are expressed in another study [18]. SEM studies were taken by an SEM-EDX device with VEGA software. Surface area and particle-size distribution were measured using Micrometrics Instrument Corporation and BET adsorption models and the results were analyzed with TriStar II 3020 Version 3.02. The $\mathrm{Cr}(\mathrm{VI})$ reduction experiment was carried out in a glass bioreactor with an effective volume of 2 liters. In this study, cellulose polyaniline was used as a biocathode. It was placed in a frame of stainless steel mesh to have the intended shape and to distribute the current uniformly across the biocathode. DC power supply (Sanjesh, Iran) was used to supply the electrical energy. The reactor was filled with Postgate's B medium, micronutrients and enriched SRB microorganisms. During the start-up period, the bioreactor was operated in batch mode with a $1 \mathrm{~mA}$ current. The $\mathrm{pH}$ of the culture medium was 5 and the experiments were performed at lab temperature of $27 \pm 2{ }^{\circ} \mathrm{C}$. The adaptation of the bioreactor with the pollutant was performed at the concentrations of $10-50 \mathrm{mg} / \mathrm{L}$. Samples was passed through 0.45 filter paper to remove turbidity. The effect of the currents densities of $3,5,7$ and 10 $\mathrm{mA} / \mathrm{m}^{2}$ and $\mathrm{Cr}(\mathrm{VI})$ concentration (120-200 $\mathrm{mg} / \mathrm{L}$ ) on removal efficiency were investigated. The concentration of dissolved $\mathrm{Cr}(\mathrm{VI})$ was measured using spectrophotometer UV-VIS9200 based on the standard method at a wavelength of $540 \mathrm{~nm}$. The ICP was analyzed using ICPS-7000 ver. 2 instrument to determine the total concentration of chromium in bioreactor's wastewater and sludge. In this way, $0.5 \mathrm{~g}$ of the bioreactor's sediment was weighed and digested in a mixture of hydrochloric acid and nitric acid. $\mathrm{Cr}$ (VI) removal efficiency was calculated through the formula .

$$
\frac{c_{0}-c_{e}}{c_{i}} \times 100
$$

Kinetics of $\mathrm{Cr}(\mathrm{VI})$ removal was calculated using the following formula In $C_{0} / C_{e}=K o b_{s} \times t$, where, $K o b_{s}$ is rate constant of the pseudo-first order $\left(\mathrm{h}^{-1}\right), t$ is time $(h)$, and $\mathrm{C}_{0}$ and $\mathrm{C}_{\mathrm{e}}$ are concentrations in $\mathrm{mg} / \mathrm{L}$.

\section{Results \& Discussion}

\section{Chromium removal in the bioelectrochemical system}

Complete removal of $\mathrm{Cr}(\mathrm{VI})$ with $10-50 \mathrm{mg} / \mathrm{L}$ concentrations occurred within an hour in the $\mathrm{pH} 5$ and induced current $1 \mathrm{~mA}$. Previous adaptation of the bacteria with the pollutant and electric current application might have led to the high efficiency. Increasing the concentration of chromium to $200 \mathrm{mg} / \mathrm{L}$ resulted in increased time required to reach the previous efficiency. The time required to achieve removal of the 120, 150, 180, and $200 \mathrm{mg} / \mathrm{L}$ concentrations of $\mathrm{Cr}(\mathrm{VI})$ were obtained 9, 12, 18 and 24 hours, respectively. The continued operation of the system at a concentration of $200 \mathrm{mg} / \mathrm{L}$ led to the reduction of efficiency to $83 \%$ (Fig. 1). Chromium is a highly toxic pollutant that reduces microbial activity at concentrations above $50 \mathrm{mg} / \mathrm{L}$ [19-21]. The obtained results showed that the biological control system could not reduce the chromium concentration of $200 \mathrm{mg} / \mathrm{L}$. The electrochemical control system had little 
effect on the removal of $\mathrm{Cr}(\mathrm{VI})$. Studies have indicated that the removal of $\mathrm{Cr}(\mathrm{VI})$ in biological systems requires a very long time. Marques et al. investigated the removal of chromium and lead ( 80 and 200 ppm) with SRB and reached an efficiency of $90 \%$ in chromium removal and $65 \%$ in lead removal after 180 hours. Verma et al. investigated the removal of $50 \mathrm{mg} / \mathrm{L} \mathrm{Cr}(\mathrm{VI})$, sulfate, and COD in SRB environment with a retention time of 7 days, $\mathrm{pH}$ of 7, at $37^{\circ} \mathrm{C}$ and achieved $76 \%, 77 \%$ and $87 \%$ removal of chromium, sulfate, and COD, respectively [22]. The obtained results shows that the biological adaptation time was lower than the other simmilar biological process. That might be due to the effects of appropriate electrical stimulation in the bioelectrochemical system containing SRB. Chun et al. studied the decomposition of PCBs in sediments and reported the best PCB removal efficiency by SRB at a voltage of $1.5 \mathrm{v}$ [23]. The mass transfer, one of the main factors that affect the performance of biological processes, is affected by electrical stimulations. Electrical field increases permeability and bacterial membrane conductivity. The reduction of chromate can be monitored by the disappearance of its distinctive yellow color. Under optimal conditions ( $\mathrm{pH} 7$, induced current $6 \mathrm{~mA}$, and $\mathrm{Cr}(\mathrm{VI})$ concentration of $200 \mathrm{mg} / \mathrm{L}$ ) the yellow color of chromium disappeared within 6 hours. No chromium was detected in the effluent, sludge, and biofilm. These deposits can be $\mathrm{Cr}(\mathrm{OH})_{3}$ formed because of the reduction of chromate with sulfide ions from the reduction of sulfate ions under anaerobic conditions. The simmilar results was reported by other resechers [24]. Chromium mass balance in the bioreduction system showed that most of the $\mathrm{Cr}(\mathrm{VI})$ was deposited at the bottom of the bioreactor. Based of the mass balance calculations, total $\mathrm{Cr}(\mathrm{VI})$ in biofilms was $8.5 \%$ (Table 1 ).

Table 1

Mass balance of $\mathrm{Cr}(\mathrm{VI})$ in the bioreduction system during 24 hour

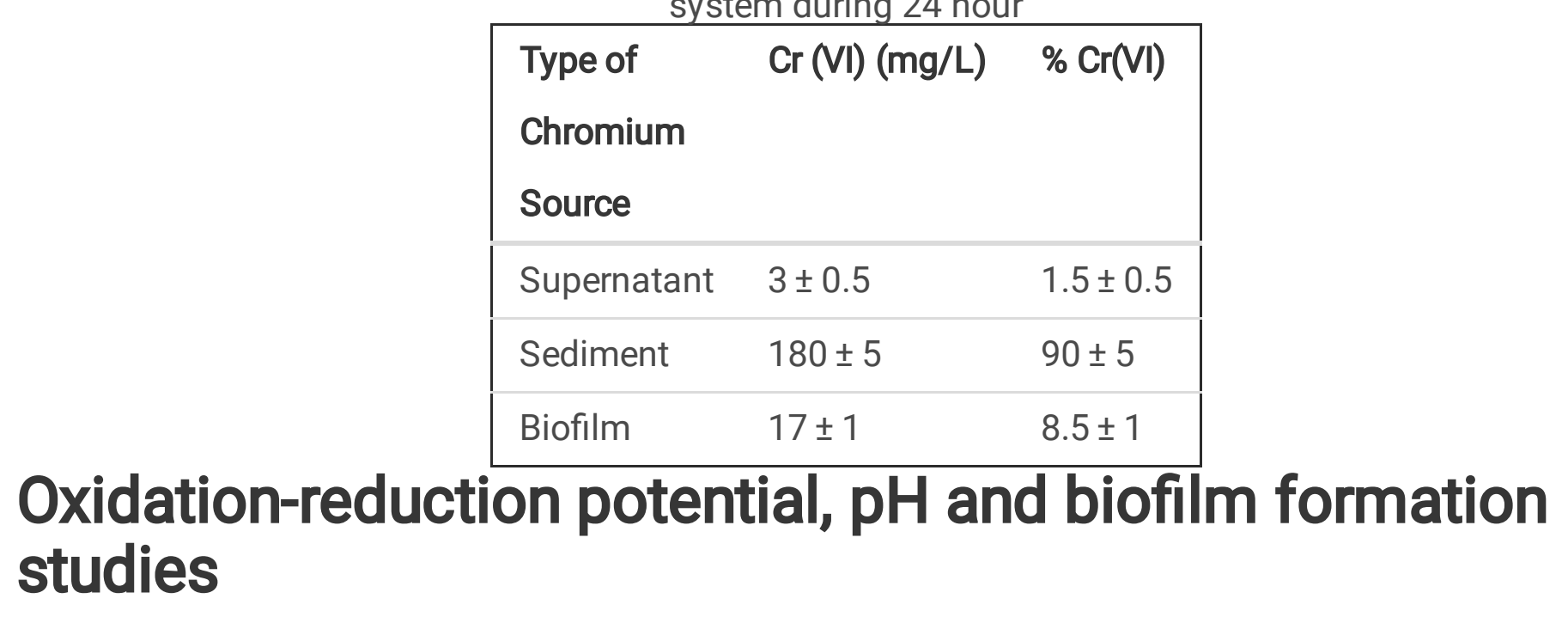

The $\mathrm{pH}$ and oxidation-reduction potential obtained results of the bioreactor adaptation with the pollutant using $1 \mathrm{~mA}$ electric current during 10 days showed that $\mathrm{pH}$ increased from 4.9 to 7.5-7.6. At the same time, the oxidation-reduction potential (ORP) reduced to $-340 \mathrm{mV}$. Incrasing of iron sulfide in the system increased $\mathrm{pH}$, reduced ORP and dispread of hydrogen sulfide odor in the bioelectrochemical system [25]. The biocathode morphology was studied before and after the formation of the biofilm using SEM. Figure 2a shows that the biocathode has a porous structure that can provide the necessary sites for 
bacterial attachment. The Fig. $2 \mathrm{~b}$ shows the good density of SRB on the biocathode. It shows the presence of bacterial cells and sediments formed on the $\mathrm{MC} /$ polyaniline film. The bacteria formed a considerable amount of biofilm and were in a position attached to the film. Uniform distribution and no changes in the basic shape of SRB are also clearly visible. EDX spectrum confirmed the presence of peak chromium sediments, indicating that the sediment contains an insoluble form of chromium (Fig. 3). The BJH analysis revealed that the particle-size distribution in the biocathode was $0.9 \mathrm{~nm}$. Generally, typical size of the bacteria is less than $5 \mu \mathrm{m}$, therefore the bacteria were attached on the biocathode surface and reduce the $\mathrm{Cr}(\mathrm{VI})$. The electric field can strengthen the $\mathrm{Cr}(\mathrm{VI})$ removal conditions and thus provide the conditions for bioreduction of SRB. The electric current intensified the formation of extracellular polymers and accelerated the bacterial cell growth on the surface of the cathode. Metal deposits were clearly visible in some parts of the biofilm. Using appropriate surfaces as biocathodes is essential for the removal of pollutants. Appropriate surfaces, such as $\mathrm{MC}$ /polyaniline with such characteristics as good electrical resistance and mechanical strength, non-toxicity for microorganisms, are essential for the enhancement of electrocatalytic activities of SRB in the removal of heavy metals. Liu et al. reported that electric current in the biofilms has a positive impact on the growth and survival of microorganisms and the applied voltage must be appropriate for the growth of microorganisms [26].

\section{The effect of induced current on the removal of $\mathrm{Cr}(\mathrm{VI})$}

The effect of induced current studies of the $\mathrm{Cr}(\mathrm{VI})$ removal shows that the highest removal efficiency was obtained in the induced current of $6 \mathrm{~mA}$. The bioreactor reached to complete $\mathrm{Cr}(\mathrm{VI})$ bioreduction during 9 hours. The voltage was always about 1-1.2 V. These results suggest that appropriate electro-stimulation has positive effects on the bacteria activity. Various studies have shown that the induced current increase in certain limits can contribute to increasing the activity of bacteria and contaminant removal efficiency. She et al. showed that the direct currents up to $10 \mathrm{~mA}$ had a significant increase in bacterial density but higher currents result in the formation of $\mathrm{O}_{3}$ and ${ }^{\mathrm{D}} \mathrm{OH}$ radicals which disrupt the bacteria [27]. It was reported that, applying an electric current to a system containing Thiobacillus ferroxidase bacteria increased the growth 10 times more than the conditions without an electric current [28]. The present study also revealed that the proper amount of $6 \mathrm{~mA}$ electric current can reduce the time required for removal of $\mathrm{Cr}(\mathrm{VI})$. Kinetics of chromium removal were calculated in different current densities $\left(\mathrm{R}^{2}=0.9\right)$. The results showed the conformity of chromium removal rate with pseudo-first order kinetics. At the current of $6 \mathrm{~mA}$, rate constant was $0.62 \mathrm{~h}^{-1}$, which was more than $0.22 \mathrm{~h}^{-1}$ and $0.08 \mathrm{~h}^{-1}$ at the densities of $30 \mathrm{~mA} / \mathrm{m}^{2}$ and $10 \mathrm{~mA} / \mathrm{m}^{2}$ (Fig. 4). Liu et al. investigated the effects of electrostimulation on nitrate removal and reported

a rate constant of $0.31 \mathrm{~d}^{-1}$ at a density of $200 \mathrm{~mA} / \mathrm{m}^{2}$ [26]. Moreover, Aksu et al., 2010 was reported a rate constant of $0.08 \mathrm{~h}^{-1}$ for decolorization in BER system at $2.5 \mathrm{~V}$ [19].

\section{Energy calculations}

BER is economic and energy saving because it can enable the degradation of pollutants in low current with low energy consumption. The amount of energy used to remove $\mathrm{Cr}(\mathrm{VI})$ in the bioelectrochemical 
system was calculated using Eq. 4.

$$
\text { Energyconsumption }\left(\mathrm{kWhm}^{-3}\right)=\frac{E I t}{V_{s}}
$$

$E$ is cell voltage in volts, / is current in amperes, $t$ is time in seconds, and $V s$ is the volume of the solution in cubic meters. Energy consumption was calculated as $2.7 \times 10^{-2} \mathrm{kWhm}^{-3}$. The amount is equal to 0.008 kWhmole ${ }^{-1} \mathrm{Cr}(\mathrm{VI})($ voltage $1 \mathrm{~V})$.

The $\mathrm{Cr}(\mathrm{VI})$-reducing bacteria receive electrons from the poised cathode and catalyze the reduction of $\mathrm{Cr}$ (VI) to $\mathrm{Cr}$ (III). Mu was reported in a Acid Orange 7 decolorization using a MEC two-chamber reactor, the amount of energy consumption was $0.05-0.008$ pollutant at a voltage of $4.0 \mathrm{~V}$ (Mu et al., 2009).

\section{Conclusions}

The present study examined the effect of electric current on the removal of high concentrations of chromium in an electric bioreactor containing SRB. The maximum removal efficiency was obtained at a current of $6 \mathrm{~mA}$ (current density of $60 \mathrm{~mA} / \mathrm{m}^{2}$ ). At this current density, the bioreactor was able to reach $100 \%$ removal of chromium (200ppm) in 9 hours. The results showed the conformity of chromium removal rate with pseudo-first order kinetics. At a current of $6 \mathrm{~mA}$, a constant rate was $0.6 \mathrm{~h}^{-1}$ which was more than $0.2 \mathrm{~h}^{-1}$ and $0.08 \mathrm{~h}^{-1}$ at the currents of $3 \mathrm{~mA}$ and $1 \mathrm{~mA}$, respectively. Energy consumption was calculated as $2.7 \times 10^{-2} \mathrm{kWhm}^{-3}$ that is equal to $0.008 \mathrm{kWhmole}^{-1} \mathrm{Cr}(\mathrm{VI})$. The SEM images showed that the biofilm has formed a good density of SRB on the polyaniline-cellulose cathode. The BJH analysis revealed that the particle-size distribution in the biocathode was $0.9 \mathrm{~nm}$ and since the typical size of the bacteria was less than $5 \mu \mathrm{m}$, the bacteria were seated on the biocathode surface and absorbed organic and inorganic materials to form the necessary colonies. The EDX spectrum of system sediments showed the presence of chromium peak indicating that the sediment contained insoluble chromium.

\section{Declarations}

\section{Acknowledgements}

The authors gratefully acknowledge the technical and scientific supports provided by Tarbiat Modares University, Tehran, Iran.

\section{Compliance with Ethical Standards}

Conflict of interest The authors declare that they have no conflict of interest regarding the publication of this work. 


\section{References}

1. Julia Fernández J et al (2019) Microbial Cellulose from a Komagataeibacter intermedius Strain Isolated from Commercial Wine Vinegar. J Polymers Environ 27: 956-

967. https://doi.org/10.1007/s10924-019-01403-4

2. Hussain $Z$ et al (2019) Production of bacterial cellulose from industrial wastes: a review. Cellulose 26: 2895-2911. https://doi.org/10.1007/s10570-019-02307-1

3. Wang M et al (2021) Construction, mechanism and prospective of conductive polymer composites with multiple interfaces for electromagnetic interference shielding: A review. Carbon 177, 377-

402. https://doi.org/10.1016/j.carbon.2021.02.047

4. Oliveira ACS et al (2019) Chitosan/Polyaniline Conductive Blends for Developing Packaging: Electrical, Morphological, Structural and Thermal Properties. J polymers Environ 27: 2150 2258. https://doi.org/10.1007/s10924-019-01519-7

5. Eladlani $\mathrm{N}$ et al (2018) Recovery of Chromium(III) from Tannery Wastewater by Nanoparticles and Whiskers of Chitosan. J Polymers Environ 26: 152-157. https://doi.org/10.1007/s10924-016-0926-6. Fernandes PM et al (2018) Bioremediation strategies for chromium removal: Current research, scale-up approach and future perspectives. 208: 139-148. https://doi.org/10.1007/s10924-016-0926-9

7. Mitra S, Sarkar A, Sen S (2017) Removal of chromium from industrial effluents using nanotechnology: a review. Nanotechnol Environ Eng 2, 11: https://doi.org/10.1007/s41204-017-0022-y

8. Jobby R, Jha P, Yadav AK, Desai N (2018) Biosorption and biotransformation of hexavalent chromium [Cr(VI)]: A comprehensive review. Chemosphere 207:255-

266. https://doi.org/10.1016/j.chemosphere.2018.05.050

9. Karimi-Maleh $\mathrm{H}$ (2021) Recent advances in removal techniques of $\mathrm{Cr}(\mathrm{VI})$ toxic ion from aqueous solution: A comprehensive review. J Molecular Liq 329:

115062. https://doi.org/10.1016/j.molliq.2020.115062

10. Wu P (2020) Extracting heavy metals from electroplating sludge by acid and bioelectrical leaching using Acidithiobacillus ferrooxidans, Hydrometallurgy 191, 105115, https://doi.org/10.1016/j.hydromet.2019.105225

11. Zou L, Huang YH, Long Ze (2019) On-going applications of Shewanella species in microbial electrochemical system for bioenergy, bioremediation and biosensing. World J Microbiol Biotechnol 35, 9 . https://doi.org/10.1007/s11274-018-2576-7

12. Logan BE, Rossi R, Ragab A (2019) Electroactive microorganisms in bioelectrochemical systems. Nat Rev Microbiol 17: 307-319. https://doi.org/10.1038/s41579-019-0173-x 
13. We X (2017) Effect of MWCNT-modified graphite felts on hexavalent chromium removal in biocathode microbial fuel cells. RSC Adv 7: 53932-53940. DOI: 10.1039/C7RA11696A

14. Dominguez-Garay A, Esteve-Nanez A (2018) Designing strategies for operating Microbial Electrochemical Systems to clean up polluted soils under non-flooded conditions. Bioelectrochem 124:142-148. https://doi.org/10.1016/j.bioelechem.2018.03.006

15. Jain P, Sharma M, Dureja P, Sarma PM (2017) Bioelectrochemical approaches for removal of sulfate, hydrocarbon and salinity from produced water, Chemosphere 166: 96108, https://doi.org/10.1016/j.chemosphere.2016.09.081

16. Hao, T-W et al (2014) A review of biological sulfate conversions in wastewater treatment. Water Res 65:1-21. https://doi.org/10.1016/j.watres.2014.06.043

17. Gacitua M A, Munoz E, Gonzalez B (2018) Bioelectrochemical sulphate reduction on batch reactors: Effect of inoculum-type and applied potential on sulphate consumption and pH, Bioelectrochemistry 119, 26-32. https://doi.org/10.1016/j.bioelechem.2017.08.006

18. Loloei M, Rezaee A, Roohaghdam AS, Aliofkhazraei M (2017) Conductive microbial cellulose as a novel biocathode for $\mathrm{Cr}(\mathrm{VI})$ bioreduction. Carbohydrate Polymer 162: 56-61.

https://doi.org/10.1016/j.carbpol.2017.01.046.

19. Aksu Z, Kılıç NK, Ertuğrul S, Dönmez G (2007) Inhibitory effects of chromium (VI) and Remazol Black $\mathrm{B}$ on chromium ( $\mathrm{VI}$ ) and dyestuff removals by Trametes versicolor. Enzyme Microbial Technol 40:116774 https://doi.org/10.1016/j.enzmictec.2006.08.024

20. Kim YM, Park H, Chandran K (2016) Nitrification inhibition by hexavalent chromium $\mathrm{Cr}(\mathrm{VI})$ - Microbial ecology, gene expression and off-gas emissions. Water Res 92: 254-61

https://doi.org/10.1016/j.watres.2016.01.042

21. Márquez-Reyes JM et al (2013) Removal of chromium and lead by a sulfate-reducing consortium using peat moss as carbon source. Bioresource Technol 144:128-

34. https://doi.org/10.1016/j.biortech.2013.06.067

22. Verma A, Dua R, Singh A, Bishnoi NR (2015) Biogenic sulfides for sequestration of $\mathrm{Cr}(\mathrm{VI}), \mathrm{COD}$ and sulfate from synthetic wastewater. Water Sci 29:19-25. https://doi.org/10.1016/j.wsj.2015.03.001

23. Chun CL, Payne RB, Sowers KR, May HD (2013) Electrical stimulation of microbial PCB degradation in sediment. Water Res 47:141-52. 10.1016/j.watres.2012.09.038

24. Smith W, Gadd G (2000) Reduction and precipitation of chromate by mixed culture sulphate-reducing bacterial biofilms. J Appl Microbiol 88:983-91. 10.1046/j.1365-2672.2000.01066.x 
25. Jong T, Parry, DL (2003) Removal of sulfate and heavy metals by sulfate reducing bacteria in shortterm bench scale upflow anaerobic packed bed reactor runs. Water Res 37: 3379-3389.

26. Liu S (2015) Effect of direct electrical stimulation on decolorization and degradation of azo dye reactive brilliant red X-3B in biofilm-electrode reactors. Biochem Eng J 93:294-

302. https://doi.org/10.1016/j.bej.2014.11.002

27. She P (2006) Electrolytic stimulation of bacteria Enterobacter dissolvens by a direct current. Biochem Eng J 28:23-9 https://doi.org/10.1016/j.bej.2005.08.033

28. Li X (2010) Direct current stimulation of Thiobacillus ferrooxidans bacterial metabolism in a bioelectrical reactor without cation-specific membrane. Bioresource Technol 101: 6035-

8.10.1016/j.biortech.2010.02.094

29. Mu Y (2009) Decolorization of azo dyes in bioelectrochemical systems. Environ Sci Technol 43:513743. https://doi.org/10.1021/es900057f

\section{Figures}

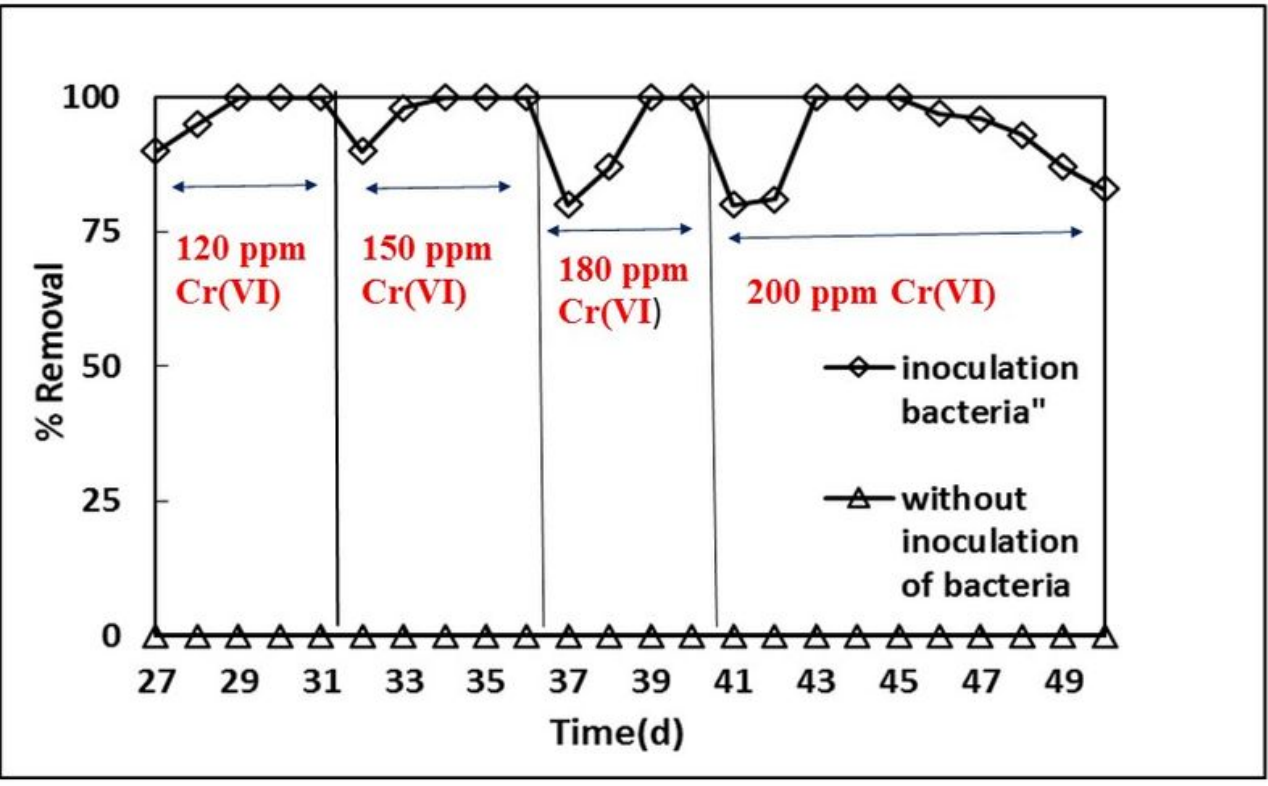

\section{Figure 1}

$\mathrm{Cr}(\mathrm{VI})$ removal efficiency in bioelectrical system ( $\mathrm{pH} \mathrm{5,6} \mathrm{mA} \mathrm{Induced} \mathrm{current,} \mathrm{Continous} \mathrm{operation)}$ 

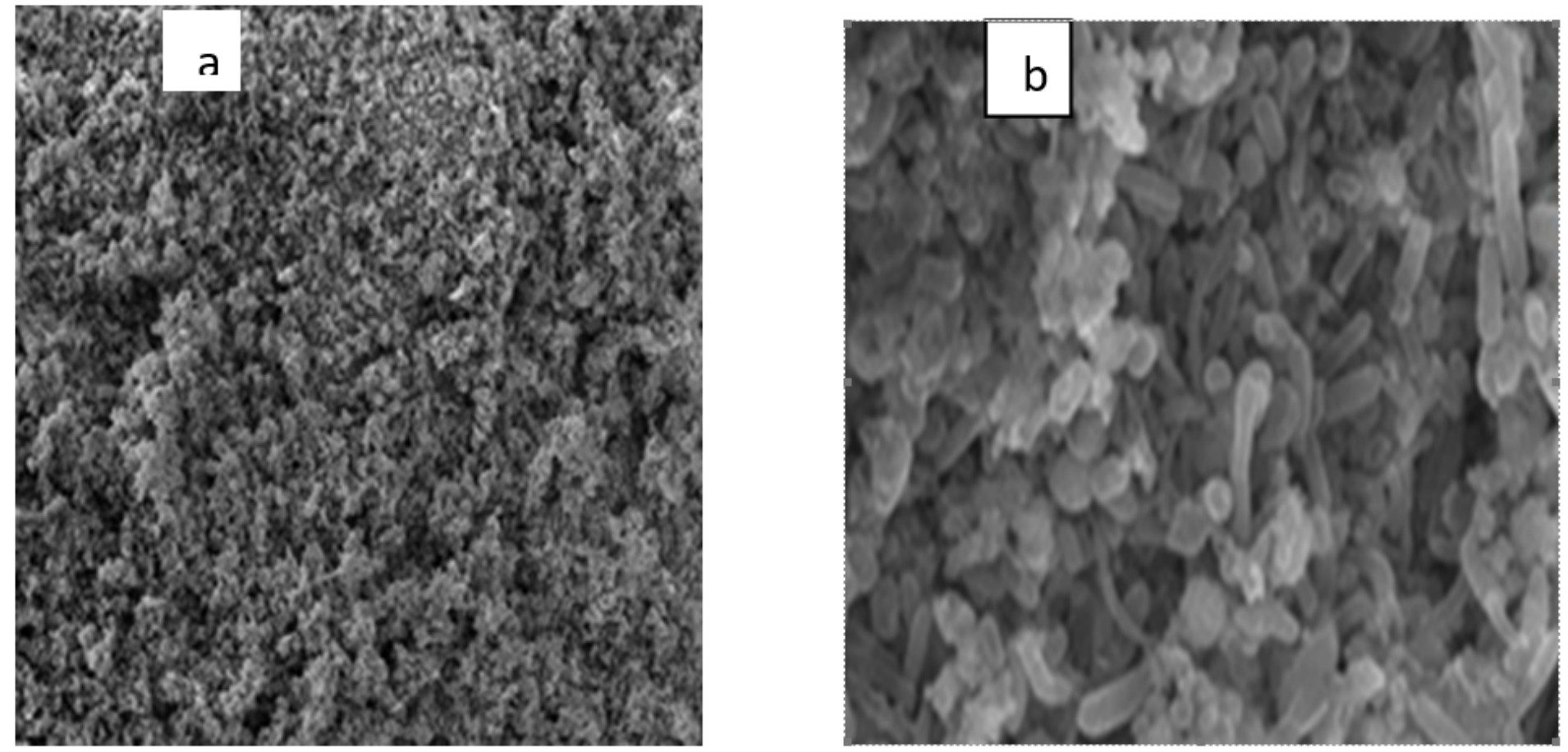

Figure 2

(a) $\mathrm{MC} /$ polyaniline ; (b) MC/ polyaniline with immobilized SRB

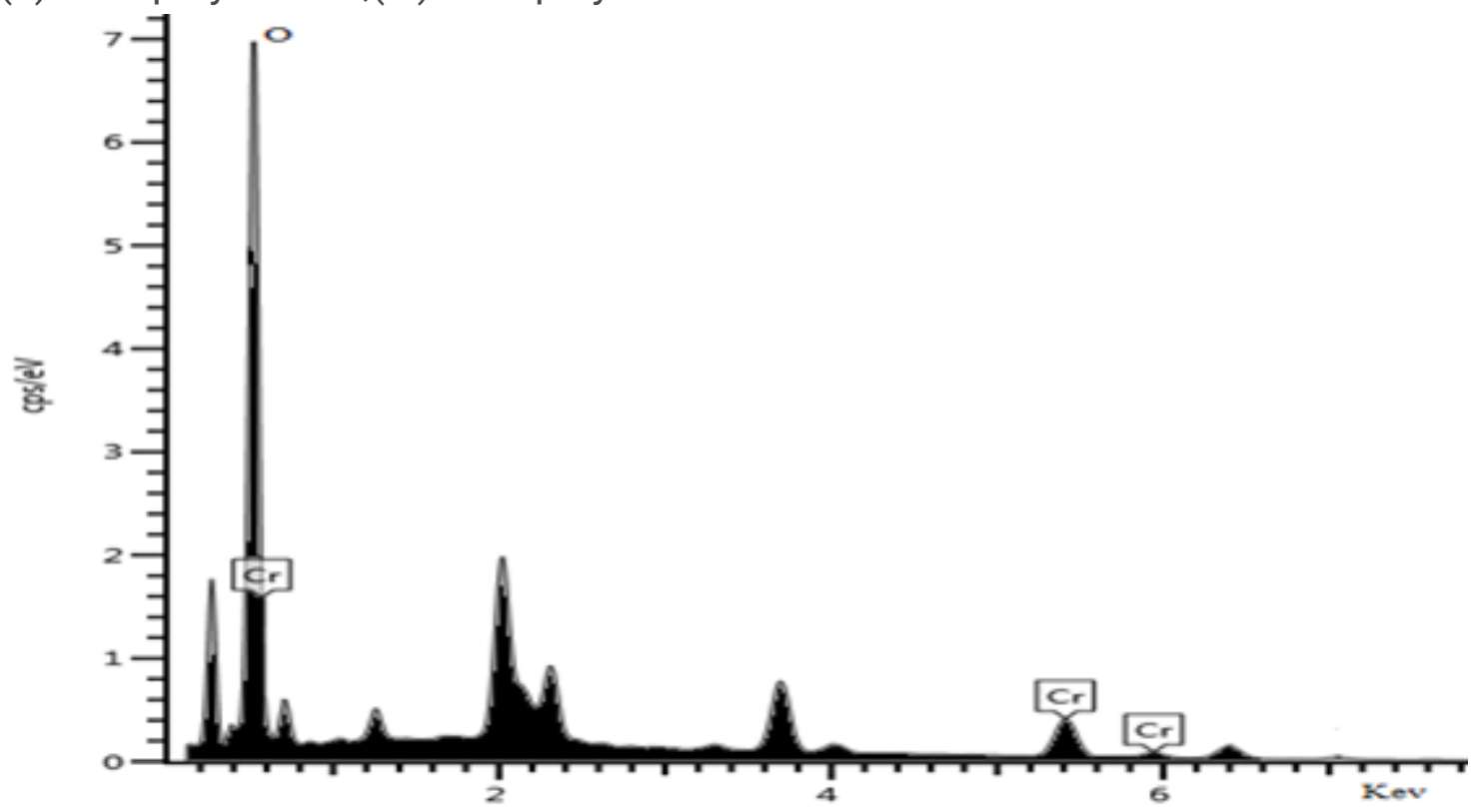

Figure 3

EDXA spectra obtained from the insoluble precipitate formed in bioreduction system. 


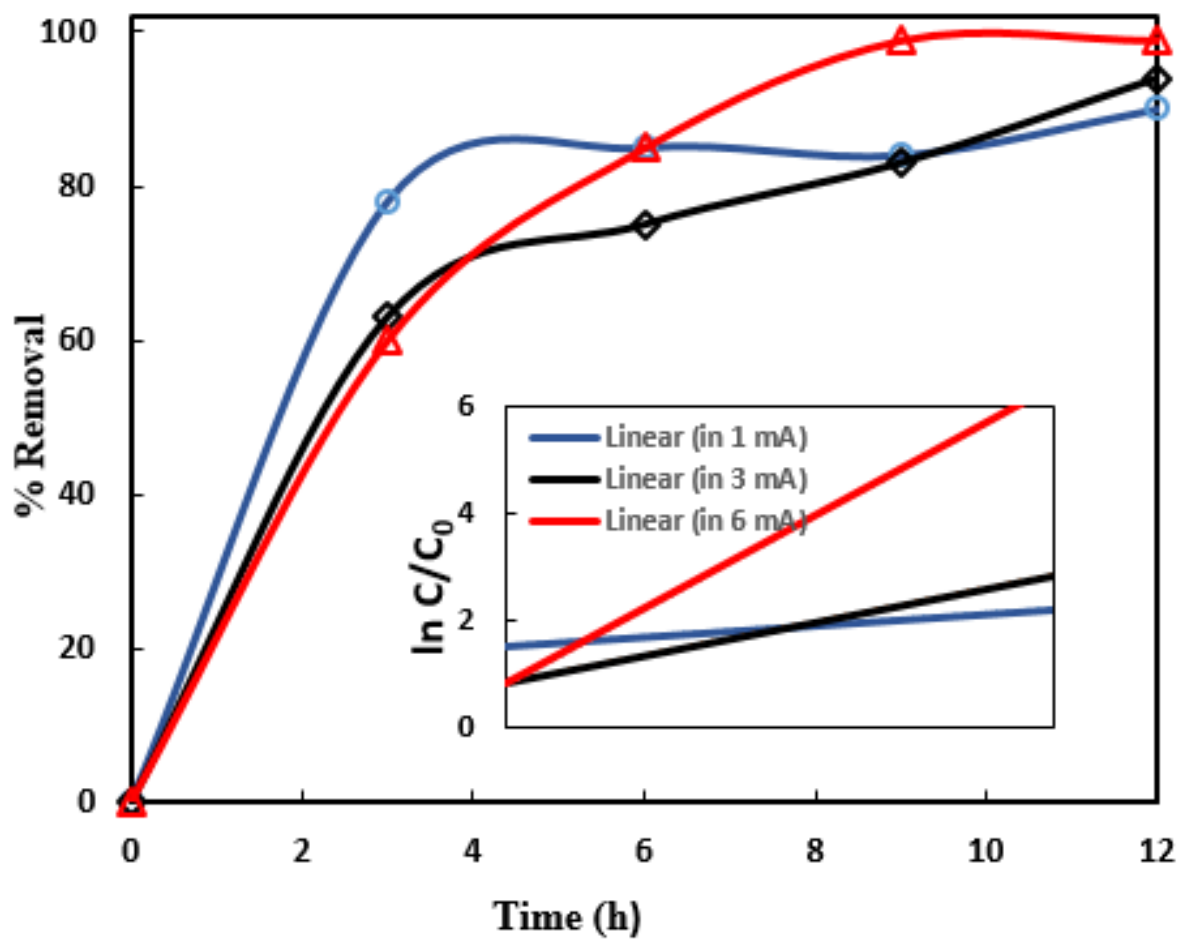

Figure 4

The effect of induced current density on $\mathrm{Cr}(\mathrm{VI})$ removal $(\mathrm{Cr}(\mathrm{VI})$ concentration $200 \mathrm{mg} / \mathrm{l}, \mathrm{pH}$ 5, Time 12h)

\section{Supplementary Files}

This is a list of supplementary files associated with this preprint. Click to download.

- graphicalAbstract.jpg 